\title{
Pengaruh Metode Pembelajaran dan Minat Belajar Siswa terhadap Keterampilan Menulis Cerita Pendek
}

\author{
Lisna Ningrum ${ }^{1)}$ \\ Universitas Indraprasta PGRI \\ Jalan Nangka No. 58 C/TB. Simatupang, Tanjung Barat, Jakarta Selatan 12530 \\ Sumaryoto ${ }^{2}$ \\ Universitas Indraprasta PGRI \\ Jalan Nangka No. 58 C/TB. Simatupang, Tanjung Barat, Jakarta Selatan 12530 \\ Nurdin ${ }^{3)}$ \\ Universitas Indraprasta PGRI \\ Jalan Nangka No. 58 C/TB. Simatupang, Tanjung Barat, Jakarta Selatan 12530 \\ lisna.ningrum@gmail.com
}

\begin{abstract}
The objective of this research is to analyze and to assess the hypothesis about the Effect on Learning Methods and Interest in Learning on The Skill of Writing Short Stories. The hypothesis of the research consists of 1) There is significant effect learning method on the skill of writing short stories. 2) There is significant effect of interest in learning on the skills of writing short stories. 3) There is insignificant effect of interaction between learning method and interest in learning on the skills of writing short stories. The Method used in this research is Experiment method. The population is the $11^{\text {th }}$ grade students of SMA in Sukabumi, consist of 128 students. 56 students were taken as the sample, and the sampling technique used is cluster random sampling. The research instrument used in this research is essay test to create/write short stories and the test of multiple choices consist of 5 options. The test consists of 30 items. The result shows that there is significant effect learning methods on the skill of writing short stories with sig of $=0.001<0.05$ and $F_{\text {count }}=5.662$ and there is significant effect of interest in learning on the skill of writing short stories with sig of $0.001<0.05$ and $F_{\text {count }}=13.457$, and there is insignificant effect of interaction between learning methods and interest in learning on the skill of writing short stories with sig of $=0.921>0.05$ and $F_{\text {count }}=0.010$.
\end{abstract}

Keywords: Learning Methods, Interest to Learn, Short Stories Writing Skills

\begin{abstract}
Abstrak
Tujuan dari penelitian ini adalah untuk mengetahui hasil analisis mengenai: 1)Pengaruh metode pembelajaran terhadap keterampilan menulis cerita pendek siswa kelas XI SMA Negeri di Kabupaten Sukabumi. 2)Pengaruh minat belajar terhadap keterampilan menulis cerita pendek siswa kelas XI SMA Negeri di Kabupaten Sukabumi. 3)Pengaruh interaksi antara metode pembelajaran dan minat belajar terhadap keterampilan menulis cerita pendek siswa kelas XI SMA Negeri di Kabupaten Sukabumi. Sampel yang digunakan dalam penelitian ini adalah sebanyak 56 siswa, yang dilakukan dengan teknik sampling cluster random sampling. Dari hasil analisis menunjukkan adanya pengaruh yang signifikan metode pembelajaran terhadap keterampilan menulis cerita pendek dengan nilai sig $=0,021<0,05 \mathrm{~F}_{\text {hitung }} 5,662$ dan terdapat pengaruh yang signifikan minat belajar siswa terhadap keterampilan menulis cerita pendek dengan nilai sig $0,001<0,05 \mathrm{~F}_{\text {hitung }} 13,457$ serta terdapat pengaruh yang tidak signifikan interaksi metode pembelajaran dan minat belajar siswa terhadap keterampilan menulis cerita pendek dengan nilai sig $0,921>0,05 \mathrm{~F}_{\text {hitung }} 0,010$.
\end{abstract}

Kata Kunci: Metode Pembelajaran, Minat Belajar, Keterampilan Menulis Cerita Pendek. 


\section{PENDAHULUAN}

Pengajaran Bahasa Indonesia pada hakikatnya adalah pengajaran keterampilan berbahasa, dan keterampilan berbahasa dalam pengajaran bahasa Indonesia adalah keterampilan reseptif (mendengarkan dan membaca) dan keterampilan produktif (menulis dan berbicara). Pengajaran berbahasa diawali dengan pengajaran keterampilan reseptif, sedangkan keterampilan produktif muncul pada tahapan selanjutnya. Peningkatan kedua keterampilan tersebut akan menyatu sebagai kegiatan berbahasa yang terpadu.

Dalam Bahasa Indonesia, ada empat macam keterampilan berbahasa yaitu keterampilan mendengarkan, keterampilan berbicara, keterampilan membaca, dan keterampilan menulis. Keterampilan menulis perlu dimiliki oleh seorang peserta didik. Aspek menulis sebenarnya sudah ada sejak di pendidikan dasar. Namun, hal ini tidak lantas membuat siswa menjadi terampil menulis. Tidak jarang ditemui siswa-siswi masih kesulitan saat ada kegiatan menulis. Siswa masih sulit untuk menemukan ide apalagi mengembangkan ide yang dimilikinya ke dalam tulisan. Hal ini menjadi kendala utama mengingat syarat untuk mampu menulis dengan kualitas baik dibutuhkan ide atau gagasan yang memadai. Semakin matang ide yang muncul di kepala, semakin bagus juga kualitas tulisan yang dihasilkan (Sayuti, 2009: 18)

Di samping keterampilan berbahasa, siswa juga dibekali keterampilan bersastra. Akan tetapi, dewasa ini permasalahan yang muncul dalam pendidikan Bahasa Indonesia adalah pembelajaran sastra. Pembelajaran sastra kurang mengarah kepada hal-hal yang apresiatif dan ekspresif, tetapi lebih menitikberatkan segi teori dan historisnya. Keberhasilan pembelajaran apresiasi sastra di setiap jenjang pendidikan sampai saat ini masih bersifat teoretis dan verbalitas. Masih banyak guru sastra menjejali para siswanya dengan teori-teori sastra. Akibatnya adalah pembelajaran sastra menjadi suatu kegiatan belajar mengajar yang membosankan. Salah satu kompetensi yang harus dikuasai siswa kelas XI SMA berdasarkan Kurikulum 2013 yaitu menulis cerpen, yakni menuliskan pengalaman pribadi yang paling menarik dalam bentuk cerpen atau cerita pendek. Cerita pendek merupakan karya sastra yang indah, baik dari bentuknya maupun dari segi bahasanya. Untuk menikmati karya sastra secara sungguh-sungguh diperlukan tentang sastra. Tanpa pengetahuan yang cukup, penikmatan akan sebuah karya sastra hanya bersifat dangkal dan sepintas karena kurangnya pemahaman yang tepat. Salah satu pengetahuan tentang sastra khususnya prosa yaitu pengetahuan tentang unsur intrinsik dan unsur ekstrinsik. Untuk memahami unsur-unsur yang diperlukan ini minat membaca yang baik.

Berdasarkan alasan dan uraian tersebut di atas, pemanfaatan metode pembelajaran kreatif sastra, khususnya cerita pendek, sangat dibutuhkan oleh guru. Salah satu metode pembelajaran yang mengacu pada pembelajaran menulis cerita pendek adalah metode pembelajaran Show Not Tell.

Show Not Tell berlandaskan pada pendekatan quantum learning. Arti quantum adalah interaksi yang mengubah energi menjadi cahaya. Dalam pembelajaran Quantum Learning yang bertujuan meraih sebanyak mungkin"cahaya" interaksi hubungan, inspirasi agar menghasilkan energi untuk 
belajar (De Porter dan Hernacki, 2007). Show Not Tell adalah teknik untuk mempercepat pengembangan gagasan pada proses menulis dengan cara bertolak dari bentuk kalimat memberitakan, kemudian mengubahnya menjadi paragraf yang menggambarkan. Misalnya, kalimat memberitakan, kini adalah hari yang indah, perlu diubah dengan cara menggambarkannya dalam sebuah paragraf apa indah itu, hari apa kejadiannya, mengapa hari itu menjadi indah, sehingga gambaran uniknya "Ini adalah hari yang indah" yang digambarkan pada paragraf.

Untuk mengetahui pengaruh penggunaan metode pembelajaran Show Not Tell dalam pembelajaran menulis cerita pendek di tingkat SMA, maka perlu diadakan sebuah penelitian untuk mengetahui seberapa besar pengaruh penggunaan metode pembelajaran Show Not Tell dalam pembelajaran menulis cerita pendek di kelas XI SMA Negeri di Kabupaten Sukabumi. Selain itu, untuk mengetahui apakah metode pembelajaran Show Not Tell lebih efektif digunakan dalam pembelajaran menulis cerita pendek daripada metode pembelajaran lain/tanpa menggunakan metode Show Not Tell di kelas XI SMA Negeri di Kabupaten Sukabumi.

Berdasarkan batasan masalah di atas, pokok masalah yang diteliti dirumuskan dalam pertanyaan sebagai berikut: 1) Apakah terdapat pengaruh metode pembelajaran terhadap keterampilan menulis cerita pendek siswa kelas XI SMA Negeri di Kabupaten Sukabumi? 2)Apakah terdapat pengaruh minat belajar terhadap keterampilan menulis cerita pendek siswa kelas XI SMA Negeri di Kabupaten Sukabumi? 3)Apakah terdapat pengaruh interaksi metode pembelajaran dan minat belajar terhadap keterampilan menulis cerita pendek siswa kelas XI SMA Negeri di Kabupaten Sukabumi?

Tujuan dari penelitian ini adalah untuk mengetahui: 1) Pengaruh metode pembelajaran terhadap keterampilan menulis cerita pendek siswa kelas XI SMA Negeri di Kabupaten Sukabumi. 2) Pengaruh minat belajar terhadap keterampilan menulis cerita pendek siswa kelas XI SMA Negeri di Kabupaten Sukabumi. 3) Pengaruh interaksi metode pembelajaran dan minat belajar terhadap keterampilan menulis cerita pendek siswa kelas XI SMA Negeri di Kabupaten Sukabumi.

\section{METODE}

Metode penelitian menggunakan metode eksperimen, yaitu dengan memberikan jenis perlakuan yang berbeda pada dua kelompok belajar siswa. Satu kelompok dijadikan sebagai kelompok eksperimen, yaitu diberikan perlakuan pembelajaran menulis cerita pendek dengan metode show not tell, sedangkan kelompok yang satu lagi sebagai kelompok kontrol dengan perlakuan pembelajaran konvensional/tanpa metode show not tell. Dari masing-masing kelompok kemudian dibagi ke dalam kelompok siswa minat belajar tinggi dan siswa minat belajar rendah. Penelitian ini menggunakan metode eksperimen dengan desain faktorial 2 $\mathrm{x} 2$.

\section{Populasi}

Penelitian kuantitatif tidak terlepas dari populasi dan sampel. Sugiyono (2011: 80) menyatakan bahwa populasi adalah wilayah generalisasi yang terdiri 
dari objek atau subjek yang mempunyai kualitas dan karakteristik tertentu yang ditetapkan oleh peneliti untuk dipelajari dan kemudian ditarik kesimpulannya. Populasi pada penelitian ini adalah siswa kelas XI SMA Negeri 1 Cicurug dan SMA Negeri 1 Parungkuda yang berjumlah 128 orang. Dipilih siswa kelas XI karena peneliti mengajar di sekolah tersebut dan mengajar di kelas XI parelel pada tahun pelajaran 2019/2020.

Sampel didefinisikan oleh Sugiyono (2011:73) sebagai, "Bagian dari jumlah dan karakteristik yang dimiliki oleh populasi tersebut. Jadi penelitian menggunakan sampel yang diambil dari populasi. Arikunto (2006:108) menyatakan "Apabila seseorang ingin meneliti semua elemen yang ada dalam wilayah penelitian, maka penelitiannya merupakan penelitian populasi. Penelitiannya juga bisa disebut studi populasi atau studi sensus". Arikunto (2006:131) menyatakan sampel adalah sebagian atau wakil populasi yang diteliti. Riduwan (2007: 70) menyatakan sampel adalah bagian dari populasi. Sampel penelitian adalah sebagian dari populasi yang diambil sebagai sumber data dan dapat mewakili seluruh populasi.

Dari beberapa pendapat di atas dapat ditarik kesimpulan bahwa sampel adalah bagian dari populasi yang mempunyai ciri-ciri atau keadaan tertentu yang akan diteliti. Riduwan (2007:70) menyatakan pengambilan sampel apabila subjek kurang dari 100, maka lebih baik diambil semua, sehingga penelitiannya merupakan penelitian populasi. Selanjutnya jika subjeknya besar dapat diambil antara 10\% - 15\% atau 20\% - 25\% atau lebih. Nana Sudjana (2009:6) menyatakan sampel adalah sebagian dari yang diambil populasi.

Sampel kemudian dibagi menjadi empat (4) kelas penelitian, dimana masing-masing kelas penelitian berjumlah 14 siswa. Empat (4) kelompok sampel penelitian yaitu kelompok 1: siswa dengan minat belajar tinggi dengan metode pembelajaran show not tell, kelompok 2: siswa dengan minat belajar rendah dengan metode pembelajaran show not tell, kelompok 3: siswa dengan minat belajar tinggi dengan metode pembelajaran konvensional dan kelompok 4: siswa dengan minat belajar rendah dengan metode pembelajaran konvensional.

\section{Teknik Sampling}

Teknik sampling dalam penelitian ini adalah sampling acak (Random Sampling) berdasarkan Factorial Group Design, dengan langkah sebagai berikut : (1) mendata jumlah populasi. (2) melakukan teknik pengocokan yaitu nama seluruh siswa dimasukan ke dalam tempat tertutup kemudian dilakukan pengocokan, nama yang keluar dijadikan sebagai sampel penelitian. (3) mendata anggota sampel kemudian diberikan instrumen penelitian.

\section{Teknik Pengumpulan Data}

Data adalah salah satu komponen penelitian yang penting karena tanpa data tidak akan ada penelitian. Data yang dipakai dalam penelitian haruslah data yang benar, yaitu data yang valid dan reliabel, karena jika data yang dipakai dalam penelitian merupakan data yang salah, tidak valid, dan tidak reliabel, maka akan menghasilkan informasi yang juga salah.

Teknik pengumpulan data pada penelitian ini adalah dengan menggunakan tes hasil belajar. Tes hasil belajar yang dimaksud adalah tes dalam kemampuan 
menulis cerita pendek, setelah siswa diberi perlakuan penggunaan metode show not tell. Posttest digunakan untuk melihat kemampuan akhir menulis cerita pendek siswa.Tes ini dilakukan pada kelas eksperimen dan kelas kontrol. Sedangkan data tentang minat belajar diperoleh melalui kuesioner yang disusun oleh peneliti.

\section{Variabel Penelitian}

Variabel dalam penelitian ini adalah variabel bebas 1, dalam hal ini merupakan variable treatment (X1) yaitu metode pembelajaran show not tell Variabel bebas 2, dalam hal ini sebagai variable atribut (X2), yaitu minat belajar siswa, dibedakan atas minat belajar tinggi dan minat belajar rendah. Variabel terikat, dalam hal ini sebagai variable kriterium $(\mathrm{Y})$; yaitu keterampilan menulis cerita pendek untuk kompetensi dasar menulis cerita pendek dengan memperhatikan unsur pembangunnya.

Penelitian ini mengandung 2 validitas, yaitu validitas internal dan validitas eksternal. Validitas internal terkait dengan tingkat pengaruh perlakuan (treatment) atribut yang ada terhadap hasil belajar bahasa Indonesia siswa, yang didasarkan atas ketepatan prosedur dan data yang dikumpulkan serta penarikan kesimpulan. Sedangkan validitas eksternal terkait dengan dapat tidaknya hasil penelitian ini untuk digeneralisasikan pada subjek lain yang tidak memiliki kondisi dan karakteristik sama. Agar tujuan tersebut tercapai, maka dalam penelitian ini dilakukan pengontrolan pengaruh variabel-variabel ekstra sebagai berikut :

1. Pengaruh variabel sejarah, dikontrol dengan pemberian materi pelajaran yang sama, dalam jangka waktu yang sama dan oleh guru yang sama.

2. Pengaruh variabel kematangan, dikontrol dengan cara proses treatment dalam variable internal waktu yang tidak terlalu lama. Dengan demikian diharapkan mereka memiliki kesempatan perubahan mental maupun fisik yang sama pula.

3. Pengaruh variabel pretesting, dikontrol dengan jalan tidak memberikan pretest pada kedua kelompok sample. Hal ini dilakukan agar pengalaman pretest tersebut tidak mempengaruhi penampilan subjek selama proses perlakuan.

4. Pengaruh variabel instrument, dikontrol dengan pemberian test yang sama pada kelompok eksperimen dan kontrol.

5. Pengaruh variabel mortalitas, dikontrol dengan pemberian perlakuan yang sama pada siswa lain yang tidak menjadi anggota sample, sehingga jika terjadi mortalitas dapat secepatnya diganti dengan siswa lain yang setara.

6. Pengaruh interaksi antar subjek, dikontrol dengan tidak memberitahukan, bahwa sedang dilakukan proses penelitian dan memberikan kegiatan proses pembelajaran yang berbeda.

Sebagai usaha mengontrol validitas eksternal dilakukan sebagai berikut:

1. Interaksi pembelajaran dengan metode belajar dan minat belajar, dikontrol dengan pengambilan kelas eksperimen dan kontrol seimbang. Hal ini dilakukan agar kondisi awal pada kedua kelas diasumsikan sama.

2. Pengaturan penelitian reaktif, dikontrol dengan:

a. Suasana perlakuan tidak artificial sehingga tidak merasa sedang diteliti

b. Subjek tidak diberikan informasi bahwa sedang diteliti 
c. Perlakuan untuk semua siswa dalam satu kelas belajar sama baik yang dijadikan sample maupun yang tidak dijadikan sample

d. Guru diusahakan hanya satu orang untuk kedua kelas eksperimen.

\section{HASIL DAN PEMBAHASAN}

Hasil

Tabel 1. Uji Homogenitas Variabel Y Keterampilan Menulis Cerpen

Levene's Test of Equality of Error Variances ${ }^{a}$

Dependent Variable: Keterampilan Menulis Cerita Pendek

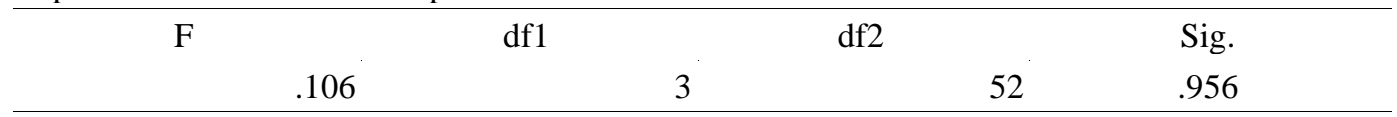

Tests the null hypothesis that the error variance of the dependent variable is equal across groups. a. Design: Intercept $+\mathrm{MP}+\mathrm{MB}+\mathrm{MP} * \mathrm{MB}$

Tabel 2. Uji Hipotesis ANOVA Dua Arah

Tests of Between-Subjects Effects

Dependent Variable: Keterampilan Menulis Cerita Pendek

\begin{tabular}{lrrrrr}
\hline \multicolumn{1}{c}{ Source } & $\begin{array}{c}\text { Type III Sum of } \\
\text { Squares }\end{array}$ & $\mathrm{df}$ & Mean Square & $\mathrm{F}$ & \multicolumn{1}{c}{ Sig. } \\
\hline Corrected Model & $139,000^{\mathrm{a}}$ & 3 & 46,333 & 6,376 &, 001 \\
Intercept & 18871,143 & 1 & 18871,143 & 2597,012 &, 000 \\
$\mathrm{~A}$ & 41,143 & 1 & 41,143 & 5,662 &, 021 \\
$\mathrm{~B}$ & 97,786 & 1 & 97,786 & 13,457 &, 001 \\
$\mathrm{~A} * \mathrm{~B}$ &, 071 & 1 &, 071 &, 010 &, 921 \\
Error & 377,857 & 52 & 7,266 & & \\
Total & 19388,000 & 56 & & & \\
Corrected Total & 516,857 & 55 & & & \\
\hline
\end{tabular}

a. R Squared $=, 269$ (Adjusted R Squared $=, 227$ )

Berdasarkan tabel 25 menunjukan bahwa nilai uji statistik KolmogorovSmimov Z A1 = 0, ,427, A2 = $0,659, \mathrm{~B} 1=0,527, \mathrm{~B} 2=0,797$ dan semua nilai Asymp. Sig. > 0,05. Hal ini menggunakan arti bahwa berdistribusi normal.

\section{Uji Homogenitas}

Dalam analisis perbedaan selain harus memenuhi asumsi bahwa data berasal dari populasi berdistribusi normal, juga harus memenuhi asumsi homogenitas varians. Uji homogenitas bertujuan untuk mengetahui apakah varian berasal dari populasi yang bersifat homogen. Pengujian homogenitas data keterampilan menulis cerita pendek siswa di lakukan dengan uji Levene pada taraf signifikan 0.05.

Dari perhitungan data diatas denga SPSS versi 20 diperoleh nilai sig $0.956>0.05$ dengan demikian Ho diterima dan Hi ditolak dan data berasal dari populasi yang homogen.

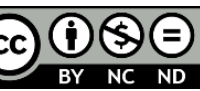

Creative Commons Attribution-NonCommercial-NoDerivatives 4.0 International License 


\section{Pengujian Hipotesis Penelitian}

Pengujian Hipotesis 1:

Dari pengujian dengan SPSS versi 20 pada tabel 29 untuk metode pembelajaran siswa didapat sig $0.021<0.05$ dengan demikian dapat disimpulkan terdapat pengaruh metode pembelajaran terhadap keterampilan menulis cerita pendek siswa SMA Negeri di Kabupaten Sukabumi.

Pengujian Hipotesis 2:

Dari pengujian dengan SPSS versi 20 pada tabel 29 didapat sig untuk minat belajar $0.01<0.05$ dengan demikian dapat disimpulkan terdapat pengaruh minat belajar terhadap keterampilan menulis cerita pendek siswa SMA Negeri di Kabupaten Sukabumi.

\section{Pengujian Hipotesis 3:}

Dari pengujian dengan SPSS 20 pada tabel 29 didapat sig untuk interaksi minat belajar dan metode pembelajaran terhadap keterampilan menulis cerita pendek $0.921>0.05$ dengan demikian Ho diterima dan Hi ditolak sehingga dapat disimpulkan tidak terdapat pengaruh interaksi minat belajar dan metode pembelajaran terhadap keterampilan menulis cerita pendek siswa SMA Negeri di Kabupaten Sukabumi. Berdasarkan hasil ini, maka uji lanjut tidak diperlukan.

\section{Pembahasan}

Pengaruh Metode Pembelajaran terhadap Keterampilan Menulis Cerita Pendek

Hasil pengujian hipotesis pertama, untuk metode pembelajaran diperoleh nilai sig $0.021<0.05$ dan $F_{h}=5,66$ dengan demikian dapat disimpulkan terdapat pengaruh yang signifikan metode pembelajaran terhadap keterampilan menulis cerita pendek siswa SMA Negeri di Kabupaten Sukabumi.

Metode pembelajaran show not tell secara spesifik ditemukan bahwa pada kelompok siswa belajar dengan metode pembelajaran show not tell hasil keterampilan menulis cerita pendek jauh lebih tinggi dari pada siswa dengan metode pembelajaran konvensional. Oleh karena itu guru harus tepat dalam memilih metode belajar bahasa Indonesia materi menulis cerita pendek agar tujuan pembelajaran dapat dicapai secara efektif dan hasil keterampilan menulis cerita pendek meningkat.

\section{Pengaruh Minat Belajar terhadap Keterampilan Menulis Cerita Pendek}

Hasil pengujian hipotesis kedua, untuk minat belajar diperoleh nilai sig $0.01<0.05$ dan $\mathrm{F}_{\mathrm{h}}=13.45$ dengan demikian dapat disimpulkan terdapat pengaruh yang signifikan minat belajar terhadap keterampilan menulis cerita pendek siswa SMA Negeri di Kabupaten Sukabumi.

Secara keseluruhan ditemukan bahwa keterampilan menulis cerita pendek siswa dengan minat belajar tinggi, lebih tinggi dari pada siswa dengan minat belajar rendah. Hal ini karena dalam proses belajar menulis cerita pendek siswa dengan 
minat belajar tinggi, siswa lebih cepat menangkap dan mengingat apa yang disampaikan oleh guru. Dengan demikian dalam upaya peningkatan hasil belajar keterampilan menulis cerita pendek hendaknya para guru perlu menumbuhkan minat belajar siswa agar tujuan pembelajaran dapat dicapai secara efektif dan hasil keterampilan menulis cerita pendek meningkat.

\section{Pengaruh Interaksi Metode Pembelajaran dan Minat Belajar Terhadap Keterampilan Menulis Cerita Pendek}

Hasil pengujian hipotesis ketiga (interaksi), untuk interaksi tersebut diperoleh nilai sig 0,921 >0,05 dan $\mathrm{Fh}=0,010$ dengan demikian dapat disimpulkan tidak terdapat pengaruh yang signifikan interaksi metode pembelajaran dan minat belajar siswa terhadap keterampilan menulis cerita pendek siswa SMA Negeri di Kabupaten Sukabumi. Hasil penelitian di atas dapat disimpulkan bahwa metode pembelajaran telah memberikan pengaruh interaksi yang tidak signifikan metode pembelajaran dan minat belajar siswa terhadap keterampilan menulis cerita pendek.

\section{PENUTUP}

Berdasarkan hasil penelitian dan pembahasan pada bab sebelumnya mengenai pengaruh metode pembelajaran dan minat belajar terhadap keterampilan menulis cerita pendek, maka diperoleh kesimpulan terdapat pengaruh yang signifikan metode pembelajaran terhadap keterampilan menulis cerita pendek. Hal ini dapat dibuktikan dengan perolehan nilai $\operatorname{Sig}=0,021<0,05$ dan Fhitung $=5,662$., terdapat pengaruh yang signifikan minat belajar siswa terhadap keterampilan menulis cerita pendek. Hal ini dapat dibuktikan dengan perolehan nilai Sig $=0,001<$ 0,05 dan Fhitung $=13,457$., dan terdapat pengaruh interaksi yang tidak signifikan metode pembelajaran dan minat belajar terhadap keterampilan menulis cerita pendek. Hal ini dapat dibuktikan dengan perolehan nilai Sig $=0,921>0,05$ dan Fhitung $=0,010$.

\section{DAFTAR PUSTAKA}

Arikunto, S. (2006). Prosedur penelitian suatu pendekatan praktik .Jakarta: Rineka Cipta.

De Porter, B., \& Mike, H. (2007). Quantum learning membiasakan belajar nyaman dan menyenangkan, Penerjemah Alwiah Abdurrahman. Bandung: Kaifa.

Poerwadarminta, W. J. S. (2004). Kamus umum bahasa Indonesia. Jakarta: Balai Pustaka.

Riduwan, M. B. A. (2007). Skala pengukuran variabel-variabel penelitian. Bandung: Alfabeta.

Sayuti, S. A. (2009). Modul menulis fiksi. Yogyakarta: PBSI FBS UNY.

Sudjana, N. (2009). Penilaian hasil proses belajar mengajar. Bandung: PT Remaja Rosdakarya. 
Diskursus: Jurnal Pendidikan Bahasa Indonesia

Vol. 3, No. 2, Agustus 2020, pp. 160-168

p-ISSN: 2615-4935

e-ISSN: 2615-4943

Sugiyono. (2011). Metode penelitian kuantitatif, kualitatif dan R\&D. Bandung: Afabeta. 